\title{
Social and Psychological Predictors of Investment Activity of Russians
}

\author{
Maria Gagarina
}

\begin{abstract}
Ph.D. in Psychology, Associate Professor, Department of Personnel Management and Psychology, Financial University; Institute of Psychology of the Russian Academy of Science, Researcher at the Laboratory of Social and Economic Psychology Mgagarina@Fa.Ru. AuthorID: 691608; SPIN: 9851-4568; ResearcherID: AAD-3036-2019; ORCID: 0000-00027812-7875; ScopusID: 15623077800
\end{abstract}

Abstract

The level of investment activity among Russians is rather low; that is why the understanding it predictors is of great importance. First, I presented an overview of Russian and international studies of psychological aspects of investment behaviour. Further, I discussed the results of the empirical research using the following sample: 360 respondents from 18 to 68 years old (average age 26 years). In my research, I used methods: socio-demographic characteristics, investment activity, including cognitive and behavioural readiness to invest in different financial instruments, and calculated index of investment activity. As concerns implementation of specific psychodiagnostic methods, I used the Questionnaire of tolerance and intolerance to ambiguity, Personal factors of decision-making, Semantic differential, and Big Five short portrait questionnaire (BF 5-10). The predictors of Russians' investment activity, including their willingness to invest in cryptocurrencies, show a positive perception of bitcoin, high emotional stability, low intolerance to uncertainty, low rationality, and low kindness to other people.

Keywords: economic psychology; investment activity; financial instruments; crypto-currency, psychological factors of investment activities

JEL Classifications: D81, D84, D87, E22, G02

\section{The Relevance of the Study and Background}

Investments of people in financial market instruments are one of the conditions for its stable functioning. In this regard, it is necessary to develop a unified strategy for attracting public funds and intensify the process of creating new types of investment products (Bezsmertnaya, 2016). Experts link new directions in the development of psychology primarily with digital technologies (Yurevich et al., 2018). At the same time, the active introduction of informational and digital technology in our life brings not only new opportunities for economic development, but also new threats, and, therefore, requires studying the attitude of people to these phenomena and determining the degree of understanding of the processes.
The development of new financial technologies, the emergence of cryptocurrencies opens up new opportunities for investment to a wide range of Internet users. It also expands the investment opportunities for non-professional traders. However, there is a danger that the influx of unqualified investors into the financial market will result in their unjustified use of financial instruments with a high level of risk. It can lead to significant losses and undermine the already low public confidence in the stock market. Many foreign authors already see in Bitcoin the features of a financial pyramid. So, the head of the European Central Bank, Yves Mersch and the head of the World Bank, Jim Yong Kim, criticised cryptocurrencies and compared them with the form of financial pyramids created by Charles Ponzi in the early XX century. In the scientific article, EngTuck Cheah and John Fry (2015) raise the issue 
of the actual cost of Bitcoin and the symptoms of a bubble in the cryptocurrency market. The authors argue that the actual value of bitcoin is zero, and its growth is mostly determined by speculation (Fry \& Cheah, 2015). Robert Schiller, 2013 Nobel Laureate in Economics, author of the theory of speculative bubbles, also advocates that Bitcoin is a bubble that is based on promises, hopes and optimism (Shiller, 2014). Thus, we approach the problem of the relationship between psychological and economic phenomena. It is essential to understand the psychological predictors of investment behaviour as well as other types of economic behaviour to make situation at the financial market more predictable.

In the field of the psychology of money, particular empirical material has already been accumulated. Attitude toward money and behaviour associated with money depends on the ongoing social changes and the individual psychological characteristics of people (Dejneka, 2002).

Many studies confirm the relationship of investment behaviour with personality traits - in particular, negative ones with extraversion, neuroticism, agreeableness and positive with consciousness (Brown \& Taylor, 2014; Nyhus \& Webley, 2001; Sutin et al., 2009). In previous works, we examined the motive of investors and found out that the respondents focused on saving, were more risk-taking and more rational than those oriented on consumption. They were also characterised by greater emotional stability (Gagarina \& Sulejmanova, 2017). Personality is undoubtedly an essential factor in determining consumer preferences and financial decision-making. Personality traits, in turn, are associated with a willingness to take risks to receive money. Consciousness also includes the ability to plan, self-discipline and the ability to defer satisfaction of needs. Lauriola and Levin (2001) suggest that emotionally stable people make more informed financial decisions. However, in laboratory experiments, it was shown that emotionally stable respondents are more prone to risk to gain profit; and respondents with high neuroticism are more likely to avoid losses (Lauriola \& Levin, 2001).

Based on the literature review, we formulated the following assumption.

Research hypothesis. The predictors of investment activity will be a positive attitude toward currencies and cryptocurrencies, emotional sta- bility, willingness to take risk and tolerance to uncertainty.

\section{Methodology}

Following the hypothesis put forward, we developed a plan for its empirical verification. The study involved 360 people living in the Russian Federation (Moscow (75 per cent), the cities of the Moscow region - Khimki, Balashikha, Dzerzhinsk, Elektrostal (14 per cent) and others, Ufa, Kazan, Tver and the region, Nizhny Novgorod, Saratov, Samara (11 per cent)), 80 per cent women, aged 18 to 68 years, average age 26 .

We surveyed information about socio-demographic characteristics of the respondents taking into account education, occupation, employment, place of residence, gender. Our study involved students, people working in organisations and individual entrepreneurs. We also assessed respondents' investment activity. Investment activity, following Zhuravlev and Poznyakov (2014) economic activity, we understand as a concept integrating various phenomena of economic consciousness and economic behaviour but limited by the area of investments. Our survey included questions about awareness of cryptocurrencies, investment experience, representations about financial instruments, experience with financial pyramids, the probability of investment behaviour in the future under certain conditions.

We intentionally included questions not only about real investment behaviour but also willing to perform it in the future (under certain conditions), as well as the desire to receive information about financial instruments, as a prerequisite for readiness for the investment behaviour. In total, ten questions were suggested: 1) Do you participate in tenders on the exchange? (yes -1 , no -0$), 2$ ) How do you assess the reliability of investing in assets that are traded on the exchange? (the presence of an assessment, regardless if it positive or negative -1 , the answer "I do not know" - 0) 3) What financial market products are you ready to invest/are investing in? (none -0 ; one product -1 ; two products -2 ; three or more - 3)) 4) Have you participated in financial pyramids in the past? (no - 0 ; yes -1 ); Are you ready to invest in financial instruments with a high level of risk and profitability? (no 0 ; yes -1$)$; 5) A question on understanding the concept of "stock" (the wrong answer is 0 ; the 
What financial market products are you ready to invest/are already investing in, and how do you assess their reliability?

\begin{tabular}{|c|c|c|c|c|c|c|}
\hline & $\begin{array}{c}\text { High risk } \\
\text { of losing } \\
\text { investments }\end{array}$ & $\begin{array}{l}\text { Unreliable, but } \\
\text { despite the risks, } \\
\text { it is possible } \\
\text { significantly to } \\
\text { increase the } \\
\text { invested funds }\end{array}$ & $\begin{array}{l}\text { Do not } \\
\text { know }\end{array}$ & $\begin{array}{l}\text { Reliable. } \\
\text { I myself } \\
\text { (or through } \\
\text { a broker) } \\
\text { manage the } \\
\text { invested funds }\end{array}$ & $\begin{array}{c}\text { I want } \\
\text { to start } \\
\text { investing in } \\
\text { such assets }\end{array}$ & Total \\
\hline $\begin{array}{l}\text { Gold and other } \\
\text { metals }\end{array}$ & 26 (27\%) & 64 (66\%) & $2(2 \%)$ & 4 (4\%) & $1(1 \%)$ & 97 (17\%) \\
\hline $\begin{array}{l}\text { Any of } \\
\text { instruments }\end{array}$ & 35 (45\%) & 33 (43\%) & $10(12 \%)$ & 0 (0\%) & 0 (0\%) & 78 (13\%) \\
\hline Currency & 38 (32\%) & 72 (60\%) & 2 (1\%) & $6(5 \%)$ & 2 (1\%) & $\begin{array}{l}120 \\
(21 \%)\end{array}$ \\
\hline $\begin{array}{l}\text { Bonds and } \\
\text { stocks }\end{array}$ & $3623 \%)$ & 97 (67\%) & $6(4 \%)$ & $13(9 \%)$ & 2 (1\%) & $\begin{array}{l}154 \\
(27 \%)\end{array}$ \\
\hline $\begin{array}{l}\text { Futures and } \\
\text { options }\end{array}$ & 3 (13\%) & 17 (77\%) & 0 (0\%) & $1(5 \%)$ & 1 (5\%) & 22 (4\%) \\
\hline $\begin{array}{l}\text { Monetary } \\
\text { instruments }\end{array}$ & 2 (10\%) & 15 (75\%) & 0 (0\%) & $3(15 \%)$ & 0 (0\%) & 20 (3\%) \\
\hline \multirow[t]{2}{*}{ Cryptocurrency } & $19(23 \%)$ & 54 (64\%) & $3(4 \%)$ & $8(9 \%)$ & $0(0 \%)$ & $84(15 \%)$ \\
\hline & 159 (28\%) & 352 (61\%) & 23 (4\%) & $36(6 \%)$ & 6 (1\%) & 575 \\
\hline
\end{tabular}

Source: Compiled by the authors based on the survey.

correct answer is 1) 6) Do you know what cryptocurrency is? (no - 0 ; yes -1$)$; 7) What sources of information about cryptocurrencies do you use? (not specified - 0; indicated -1 ); 8) Do you mine? (no, I don't know what it is -0 ; no, I know what it is -1 ; yes, but I have little idea of the mechanism - 2; yes, I fully understand the mechanism - 3); 9) What factors would have a positive impact on your decision to engage in investment activities (none - 0 ; factors indicated -1 ); Are you interested in information about new financial instruments? (no -0 , yes -1 )

We calculated the aggregate index of investment activity. The minimum empirical value is 1 , and the maximum is 15 . The average value is 6.5 .

We used the method of semantic differential (SD) to identify the features of the relationship to currency and cryptocurrency. To assess personal characteristics, we used the short portrait questionnaire "Big Five" adapted by Egorova and Parshikova (2016). 157 respondents additionally were given the questionnaire "Personal decision-making factors" by Kornilova (1994), and 203 respondents were additionally given the questionnaire "Tolerance and Intolerance uncer- tainty by S. Badner's" adapted by Kornilova and Chumakova (2014).

\section{Results and Discussion}

\section{Investment Experience}

To begin with, we analyse the data on the investment experience of the respondents. To establish which assets are most popular among the respondents, they were asked the question "What financial market products are you ready to invest/are already investing in?”. We presented the results in Table 1. We calculated the frequency of responses; the number of options may be more than one, so the total number is particular than the number of respondents.

It is important to note, the table above presents precisely the idea of peoples' willingness to invest in financial market products (and their reliability), rather than the real actions we will describe below. Most of our respondents (27 per cent) are willing to invest in stocks and bonds, while most of them assess such investments as unreliable, although with the potential to generate income. The next are investments in foreign currencies (21 per cent), 
Table 2

Investment preferences of respondents

\begin{tabular}{cc} 
Currency & 1 (3\%) \\
\hline Futures and options, Currency & $1(3 \%)$ \\
Stocks and bonds & $4(11 \%)$ \\
Stocks and bonds, Currency & $6(16 \%)$ \\
Stocks and bonds, Gold and other metals & $5(14 \%)$ \\
Stocks and bonds, Futures and options & $1(3 \%)$ \\
Monetary instruments & $5(13 \%)$ \\
Currency & $3(8 \%)$ \\
Stocks and bonds, Futures and options, Currency & $3(8 \%)$ \\
Cryptocurrency & $5(13 \%)$ \\
Stocks and bonds, Currency, Gold and other metals & $2(5 \%)$ \\
\hline
\end{tabular}

Source: Compiled by the author.

then precious metals (17 per cent) and cryptocurrencies (15 per cent). As for the reliability of investment, the most popular answer is "unreliable, but despite the risk, there is an opportunity to increase the investment significantly".

Now let's turn to real investment behaviour (see table 2 ). Only 37 people (10 per cent) of the total respondents have such experience and think about investment activity as a source of income. Real experience has 3 per cent of women and 23 per cent of men. Results, indicating low investment activity of Russians, are in agreement with studies of Bezsmertnaya (2016), showed that national characteristics are of particular importance. Most Russians characterised a saving rather than an investment model of behaviour. It is most likely due to historical circumstances, the peculiarities of our country's economic and political development, fear of losses, and a low level of literacy in the field of financial instruments (Bezsmertnaya, 2016).

Among respondents having investment experience, the most popular are investments in stocks and bonds, as well as foreign currency (frequency are 37 per cent and 28 per cent, respectively). Further, follow gold and precious metals (12 per cent), monetary instruments (10 per cent); the least popular are cryptocurrencies (8 per cent) and futures and options (5 per cent).
The results of comparing investors in financial pyramids, in traditional financial instruments and cryptocurrencies we gave in our previous article prepared as part of this study (Gagarina \& Lopanova, 2018). Since the work is not translated into English, we briefly cite them in this work. Respondents who take part in trading on the stock exchange and choose stocks and bonds for investments differ from those who do not take part in such trading because of personality traits - lower level of Consciousness and Agreeableness and do not change in the level of Tolerance and Intolerance to uncertainty. Respondents who invested in financial pyramids differ from those who do not invest in financial pyramids only at a lower level of Tolerance and Intolerance to uncertainty and do not differ in personality traits.

Respondents investing in cryptocurrencies and mining equipment differ from those who do not invest, both in terms of Tolerance and Intolerance to uncertainty, and in several personality traits. Investors are characterised by lower levels of Tolerance and Intolerance to uncertainty, lower levels of Extraversion, Openness to Experience, Consciousness and Agreeableness.

\section{Predictors of Investment Activity}

To evaluate the predictors of investment activity, we performed a linear regression analysis using 
Table 3

Regression analysis model 1

\begin{tabular}{|c|c|c|c|c|c|c|}
\hline Model & $\mathbf{R}$ & $R^{\wedge} 2$ & Adjusted $R^{\wedge} 2$ & $\begin{array}{l}\text { Standard Error of } \\
\text { the estimate }\end{array}$ & $\mathbf{F}$ & p. \\
\hline 1 & .505 & .255 & .229 & 2.5715 & 9.863 & .000 \\
\hline \multicolumn{7}{|c|}{$\begin{array}{l}\text { Dependent var.: Investment activity index } \\
\text { Predictors: constanta, Openess to experience, Rationality, Agreeableness, Evaluation (Bitcoin), Evaluation } \\
\text { (Dollar), }\end{array}$} \\
\hline
\end{tabular}

Table 4

Regression analysis model 2

\begin{tabular}{|c|c|c|c|c|c|c|}
\hline Model & $\mathbf{R}$ & $R^{\wedge} 2$ & Adjusted R^2 & $\begin{array}{l}\text { Standard Error of } \\
\text { the estimate }\end{array}$ & $\mathbf{F}$ & p. \\
\hline 2 & .410 & .168 & .147 & 2.2948 & 7.965 & .000 \\
\hline \multicolumn{7}{|c|}{$\begin{array}{l}\text { Dependent var.: Investment activity index } \\
\text { Predictors: Constanta, Intolerance to uncertainty, Agreeableness, Evaluation Bitcoin, Strength Dollar, } \\
\text { Neuroticism }\end{array}$} \\
\hline
\end{tabular}

the inverse step method. The Investment Activity Index we choose as the dependent variable. The independent variables were age, the scales of the semantic differential "Strength", "Evaluation", "Activity", the Big Five questionnaire "Extraversion", "Neuroticism", "Openness to experience", "Consciousness", "Agreeableness".

Since one part of the subjects completed the questionnaire "Personality Decision Making Factors", and the other - the questionnaire "Tolerance and Intolerance to Uncertainty", we built two models. Model 1 (Table 3) included, in addition to the independent variables indicated above, "Rationality" and "Risk-taking", and model 2 (Table 4) "Tolerance" and "Intolerance" to uncertainty.

In each case (Model 1 and Model 2), a linear regression analysis was performed using the reverse step method, and the model with the best performance was selected.

Investment activity directly depends on openness to experience (betta $=0.2$ ), the positive evaluation of bitcoin (betta $=0.3$ ) and the dollar (betta $=0.2$ ) and negatively on agreeableness (betta $=-0.3$ ) and rationality (betta $=-0.2$ ).

Thus, when we include the rationality/willingness putting risk factors in the model, significant predictors of investment activity will be as follows: high openness to experience; willingness to try and learn new; high positive value of the dollar and bitcoin; the idea of them as "good" currencies; low kindness to other people mani- fested in the priority of their own interests; being persistent, competitive or even aggressive; and low rationality. The causal relationship between the attitude to the asset and the willingness to invest (investment activity) is perceived as quite natural. The connection with low rationality can be understood as a lack of need to act with the complete information. It is vital to be able to work in a situation of uncertainty and ambiguity when operating in the financial market. As concerns the connection between "agreeableness and openness" and "experience and investment activity", the result can be compared with the work of Brown and Taylor (2014). They have found that "agreeableness will” is negatively, and "openness to a new experience" is positively correlated with "investing in stocks".

Investment activity directly depends on the positive assessment of bitcoin (betta $=0.3$ ) and indirectly on neuroticism (betta $=-0.2$ ), agreeableness $(-0.2)$, dollar strength (betta $=-0.2$ ) and intolerance to uncertainty (betta $=-0.3$ ).

That is, when we include into the model of investment activity factors "tolerance/intolerance to uncertainty", low agreeableness and a positive assessment of bitcoin remain significant, as well as high emotional stability in situations of stress and uncertainty, low intolerance to the uncertainty and perception of dollar as a weak currency (that means dependent on some external circumstances). When comparing the two mod- 
els, it is necessary to account for the concepts of intolerance to uncertainty and rationality - low indicators of which are predictors of investment activity. These two variables are interconnected: rationality, as the focus on the maximum collection of information, accompanies intolerance to uncertainty as a desire for clarity of judgment. Model 2 focuses on the ability to act in a stressful situation and withstand a high degree of uncertainty. We can conclude that high investment activity depends on emotional stability and low tendency to perceive and interpret the environment as a threatening or as a source of discomfort. Our results are consistent with Lauriola and Levin (2001), who showed in laboratory experiments that emotionally stable respondents are more prone to risk to get money.

\section{Conclusions}

Based on the study, we have drawn the following conclusions can. The investment activity of Russians is quite low. The most popular among people with investment experience are investments in stocks and bonds, as well as foreign currency. However, most of the respondents assess such investments as unreliable, although with the potential to generate income.

Men are more inclined to consider investment activity as a source of income and practice this activity.

The predictors of Russians' investment activity, including their willingness to invest in cryptocurrencies, are a positive perception of currency and cryptocurrency, high emotional stability, low intolerance to uncertainty, low rationality and high persistence and competitiveness.

\section{Funding}

The work was carried out with the financial support of the Russian Foundation for Basic Research (RFBR), grant No. 18-013-01232A "Psychological factors and mechanisms of investment behaviour of Russians with different levels of financial literacy".

\section{References}

Bezsmertnaya, E. R. (2016). Public investments into financial market tools: the current state and prospects of development [Investicii naseleniya $\mathrm{v}$ instrumenty finansovogo rynka: tekushchee sostoyanie i perspektivy razvitiya]. Ekonomika. Nalogi. Pravo, 6, 17-25.

Brown, S., \& Taylor, K. (2014). Household finances and the “Big five” personality traits. Journal of Economic Psychology, 45, 197-212.

Dejneka, O., S. (2002). The dinamic of macroeconomical component of money image in public conscious [Dinamika makroekonomicheskih komponentov obraza deneg v obydennom soznanii]. Psihologicheskij zhurnal, 23(2), 36-46.

Egorova, M. S., \& Parshikova, O. V. (2016). Validation of the Short Portrait Big Five Questionnaire (BF-10) [Psihometricheskie harakteristiki Korotkogo portretnogo oprosnika Bol'shoj pyaterki (B 5-10)]. Psihologicheskie issledovaniya, 9(45), 9. Available at: http://psystudy.ru (accessed 21.02.2018).

Fry, J., \& Cheah, E-T. (2015) Speculative bubbles in Bitcoin markets? An empirical investigation into the fundamental value of Bitcoin. Economics Letters, 130, 32-36.

Gagarina, M. A., \& Lopanova, N. K. (2018). Tolerance to uncertainty in people with different strategies of investment behaviour [Tolerantnost k neopredelennosti u lic s razlichnymi strategiyami investicionnogo povedeniya]. Internet-zhurnal «Mir nauki», 3. Available at: https://mir-nauki.com/PDF/04PSMN 318.pdf.

Gagarina, M. A., \& Sulejmanova, S. S. (2017). Financial literacy and economic behaviour of people with different relations of saving and consumption motives [Finansovaya gramotnost' i ehkonomicheskoe povedenie lic s razlichnym sootnosheniem motivov sberezheniya i potrebleniya]. Internet-zhurnal «Mir nauki», 5. Available at: http://mir-nauki.com/PDF/45PSMN 317.pdf (accessed 01.12.2019).

Kornilova, T. V., Chumakova M.A. (2014). Tolerance and intolerance of ambiguity in the modification

Kornilova, T. V. (1994). Diagnostics of personality factors in decision-making [Diagnostika "lichnostnyh faktorov" i reshenij]. Voprosy psihologii, 6, 99-109.

Lauriola, M., \& Levin, I. P. (2001) Personality traits and risky decision-making in a controlled experimental task: An exploratory study. Personality and Individual Differences, 31(2), 215-226.

Nyhus, E. K., \& Webley, P. (2001). The Role of Personality in Household Saving and Borrowing Behaviour. European Journal of Personality, 15, 85-103.

Shiller, R. J. (2014). Speculative asset prices. American Economic Review, 104, 1486-1517. 
Sutin, A. R., Costa, P. T., Miech, R., \& Eaton, W. W. (2009). Personality and career success: Concurrent and longitudinal relations. European Journal of Personality, 23(2), 71-84.

Yurevich, A. V., Zhuravlev, A. L., \& Nestik, T. A. (2018). The future of psychology and digital revolution: forecasting the development of psychological science and practice [Cifrovaya revolyuciya i budushchee psihologii: $\mathrm{k}$ prognozu razvitiya psihologicheskoj nauki i praktiki]. Institut psihologii Rossijskoj akademii nauk. Social'naya i ehkonomicheskaya psihologiya, 3, 1(9), 6-19.

Zhuravlev, A. L., \& Poznyakov, V. P. (2004). Economic psychology: theoretical problems and trends in empirical investigation [Ekonomicheskaya psihologiya: teoreticheskie problemy i napravleniya ehmpiricheskih issledovanij]. Psihologiya. Zhurnal Vysshej shkoly ehkonomiki, 1(3), 46-64. Available at: https://psy-journal.hse.ru/ data/2011/04/28/1210639564/46-64.pdf (accessed 03.05.2018).

\section{Социально-психологические предикторы инвестиционной активности россиян}

\section{Мария Анатольевна Гагарина}

Кандидат психологических наук, доцент, кафедра «Управление персоналом и психология», Финансовый университет, Москва, Россия; ассоциированный научный сотрудник лаборатории социальной и экономической психологии, Институт психологии РАН, Москва, Россия

Аннотация. Представлен обзор российских и зарубежных исследований психологических факторов и коррелятов экономического, в том числе инвестиционного, поведения и обсуждаются результаты их эмпирического исследования. Информационной базой исследования стала выборка 360 респондентов от 18 до 68 лет (средний возраст 26 лет). Исследование проведено с помощью анкетирования, в ходе которого собраны социально-демографические характеристики, выявлена инвестиционная активность (когнитивная и поведенческая готовность инвестировать в различные финансовые инструменты). Рассчитан индекс инвестиционной активности. Анкетирование проводилось с использованием психодиагностических тестов: опросника «Толерантность и Интолерантность к неопределенности», «Семантический дифференциал» (понятия «Доллар» и «Биткоин»), короткого портретного опросника «Большая пятерка» и опросника «Личностные факторы принятия решений». Предикторами инвестиционной активности россиян, включая их готовность инвестировать в криптовалюты, являлись позитивное восприятие биткоина, высокая «Эмоциональная Стабильность», низкая «Интолерантность к неопределенности», низкая «Рациональность» и высокая «Настойчивость».

Ключевые слова: экономическая психология; инвестиционная активность; финансовые инструменты; криптовалюты; психологические факторы инвестиционной активности 